\title{
A review of the fake news ecosystem in India and the need for the News Literacy project
}

\begin{abstract}
In India, in the last year alone, over 30 people have died due to child kidnapping rumors spread on social media, specifically WhatsApp. India's access to the internet shot up in the recent years with the entry of Reliance Jio which made data plans affordable and therefore accessible. WhatsApp has been the most frequently downloaded application. As the country gears up for an important election, the spread of disinformation has accelerated. The right-wing ruling party has claimed that it has over 3 million people in its WhatsApp groups. A recent study by BBC has shown that in the country, most of the disinformation has been spread by the right wing. Call it propaganda, disinformation or plain fake news, false or wrong information has become a part of the political process in India.

Moreover, the Indian media no longer seem to be standing up to the government; in the last few years, it has generally toed the government line. The reasons are many, including corporate ownership, regressive laws, and a complete bypass of the media by the powers. The Prime Minister has spoken only to a few selected media houses and has never been asked any tough questions in his five-year tenure. Furthermore, the media has been completely sidelined by this government by it going to the public, directly through social media. All of this has produced a very turgid and messy information situation.

With the government also interfering in education, it has become all the more difficult for most educators to introduce critical thinking courses in the country, even though various efforts have been made by Google News Initiative, Facebook and BBC Schools to introduce tools to debunk false information.
\end{abstract}

Key words: News Literacy, Fake news, WhatsApp, Social Media, Factchecking

ndia has just received the dubious honor of using the most data (Special Correspondent, 2019) per smartphone, at $9.8 \mathrm{~GB}$. This number, according to an Ericsson Report (Mobility Report, June 2019) is expected to double by 2024, as the country's subscriber base is expected to reach 1.42 billion by then (Press Trust of India, 2018).

Dubious because over the last year, over 30 people have died (Saldhana, Rajput, Hazare, 2018) due to child kidnapping rumors spread on social media, specifically WhatsApp. It enabled affordable access to data on inexpensive smart phones. India's access to the internet shot up (Meeker, 2018) in the recent years with the entry of Reliance Jio which made data plans affordable and therefore accessible. WhatsApp has been the most frequently downloaded application in the country. According to publicized information (Iqbal, 2019), India is the biggest WhatsApp market in the word with over 200 million users. In terms of the number of active users each month, WhatsApp emerged as the leader (Mitter, 2019).

Literacy levels in the country (Office of the Registrar, 2001) are not what they should be, and therefore, the main medium of communication on WhatsApp is video. India has also topped global rankings in hours spent on video-streaming apps. It is followed by 
Brazil and the US. "Total time spent on video streaming apps per device will grow by 110 percent from 2016 to 2019," App Annie (Sydow, 2019) estimated.

Moreover, it is quite well known that images are the most popular form of communication throughout the world. Few people are inclined to read long pieces of text, and few have the capacity or patience to download heavy videos. So, memes, cartoons and photographs (edited or otherwise), and short video clips become the most popular means of communicating on line, especially on WhatsApp.

In the recent general elections, won clearly by the right wing ruling party, BJP, WhatsApp was the main source of information (or misinformation or disinformation) for most voters. The party has itself claimed that it has over 3 million people in its WhatsApp groups (FM Staff, 2019). That was the situation a few months ago. Since then, the number is most likely to have risen.

\section{A hot line to misinformation}

It might be difficult to posit that the ruling BJP is the source for the majority of misinformation circulating online in the country. In its recent study, BBC, however, has bravely expressed that position (Chakrabarti, 2018). According to the study, most of the misinformation spread is the handiwork of the right wing. A lot of information falls under the category of propaganda, but mis- or disinformation might be a better nomenclature. The same study also indicates that misinformation also originates from other political fractions, too, but the volume put out by the right wing far exceeds the others.

In India, therefore, misinformation has become an integral part of the political process. It crosses the line over to propaganda, too, if there is such a line.

Since most of the information reaches consumers on closed, informal social media platforms, any factchecking is at most cursory, or through television, the latter in case of disasters and other such events. Work done by fact checkers is rarely shared (Chakrabarti, Duty...).

Most often, the mainstream media do not deal with political misinformation. Media debunk stories revolving around myths and urban legends - not so much political but rather social or health-related.

The other trouble is that main stream media are perceived with skepticism by people who are the target of misinformation. The reasons of the situation vary. Politicians have put target on media that do not toe their line. They are responsible for a lot of the media being called 'fake', or being given other deprecatory names like 'presstitutes' or 'sickular' (Agrawal, 2015).

With growing popularity of social media, politicians have now found a direct channel of communication with their constituencies. They no longer need the local newspaper or TV channel to disseminate information. They can do it directly, without any checks and balances of mainstream journalism. Even the prime minister himself has favoured only a few media houses, and has given interviews only to a couple of them in his earlier tenure. He has rarely spoken to the press openly, i.e. in a press conference (Ghosh, 2019) and therefore, has never been asked any tough questions. Interviews that were published 
by a couple of media houses fell only very short of hagiographies. His colleagues in the cabinet have, of course, followed suit.

So, unlike in the past when the government, or for that matter, any large entity, announces information or announcements through the media, with the arrival of social media, this role of the media has been completely eliminated. Most announcements are made online, through Twitter, Facebook, and WhatsApp.

Since information comes to them directly, consumers also tend to believe that the information could be trusted (Chakrabarti, Duty...). The logic is similar to what happens when people get disinformation from their relatives, friends or their favourite aunt. Therefore, when something contradictory is published in the mainstream media, the tendency not to believe it is quite strong.

\section{Looking the other way}

The situation becomes further messy when several large media houses in the country give up the real business of journalism and verification of news, and that of speaking truth to the authority (Special Correspondent, 2018). Most media houses ignored the trespasses of several politicians from the ruling party during the election campaign. One may recall an election-related offence which in 1975 led a gutsy judge to send the then powerful prime minister Mrs. Indira Gandhi to prison (Special Correspondent, 2018). It resulted in her imposing the emergency state. This shows how compliant the media were during the elections.

Reasons of the situation are many. Firstly, the ownership (Kaushik, 2016) is the major one. A recent study (Media Ownership Monitor, 2019) by the Media Ownership Monitor and Reporters Sans Frontiers showed that media ownership consolidated within a few corporate entities and independent media houses are few and far between. The connection between corporate owners and the government is well known. Corporations have more irons in the fire than a newspaper or a television channel, and are not likely to run the government the wrong way.

Even if the few independently-funded (even crowd-funded) media houses published a few stories, they would probably be slapped with suits and threats of legal action (Soni, 2017). Impunity is a big problem and in the last few years several journalists have been sued, imprisoned, and even killed (The Economics Times, April 18, 2018). And none of this has ever been done by government actors directly. It has been corporate media, local bureaucrats acting on their own behalf, invoking either ancient legislations or even sections of the law that have been read down by the Supreme Court of the country, as well as unknown elements.

And, if any anti-government stories did get published, and they do, they would be in niche publications that are read by only a few.

An arrangement under which political parties own media houses is quite common in some parts of the country. All one can say is that, at least here, there is transparency. The public is generally aware of the ownership, as well as inclinations of these channels.

All of this leads to a lot of skepticism around the mainstream media - warranted or otherwise - and therefore, a messy information situation. 


\section{The need for long-lasting movements}

Therefore, there is an urgent need to counteract this movement of misinformation. In India, at least, we have an entire generation growing up on information that is suspect, with even history books being altered (Correspondent , 2017) to suit the worldview of the ruling party.

Efforts have been made by global media giants - Google and Facebook in particular - to educate people on fake news and how to debunk it. Google held workshops at various levels in the country and trained over 8000 journalists in debunking fake news. Facebook, too, has made its efforts - holding workshops, and even alerting users when something on its feed had not been entirely true. Facebook has also appointed a team of the International Fact-Checking Network (IFCN) certified fact-checkers to flag content that maybe suspicious (Disclosure: the author is an assessor helping IFCN certify fact checkers).

While one cannot undermine the tremendous work being done by fact-checkers across the world, one may feel the need for something more long-lasting and substantial. Mostly, what fact-checkers do, is to identify content that might not be true and use tools to debunk it and explain why the information is not true. Also, social media platforms are pretty dynamic. People have moved from Facebook to WhatsApp and to Instagram almost seamlessly, and many verification bodies take a bit to catch up.

In India, fact-checking saw a sharp rise in interest just before the May 2019 general elections (Press Trust of India, Facebook..., 2019). Several fact-checking units applied to the IFCN for certification. There has been, of course, a corresponding dip in the applications post the elections. The interesting bit was that it was not just small players, working out of mom's living room that were going at fake news with a heavy hand. Suddenly, even large media houses like the Times of India group and the India Today group set up fact-checking units certified by the IFCN.

Several of them were hired by Facebook and other such organizations to flag explicitly untrue content. The rise in interest, obviously, was because it was a source of revenue.

However, most people who access information on social media (and that number is very large in India), as we have said before, do not put much effort to verify facts. WhatsApp content cannot be flagged because of the very nature of the platform. Facebook and Twitter have been taking steps to flag content that might not be true, but very few users are aware of the feature. Also, fact checking has been accused of being partisan (Owen, 2018).

Therefore, there is a need for something more long-lasting, something more substantial, i.e. critical thinking skills.

In a country that has set store by rote learning, where refraining from asking questions is a sign of good manners, teaching critical thinking skills is not considered essential. However, many teenagers and young people spend a lot of time online. They come across information that might be potentially misleading. Hence, they need to know how to identify such information easily by asking a few simple but important questions.

Additionally, they need to become news literate. They need to know what their news contains and how to identify suspicious content. Studies (Bulger, Davison, 2018) have shown that media literacy has resulted in positive outcomes in critical thinking skills and 
behavioural changes. The Stony Brook University's Center for News Literacy (Center for News Literacy) has a curriculum that helps young people recognize the difference between journalism and other information, as well as between news and opinion. It helps them evaluate news stories depending on the evidence provided, the amount of verification done by the journalist and the reliability of sources. It also helps them deal with bias information.

In India, efforts have centred around fact-checking. News literacy needs to be promoted and this has to be done really quickly. The country needs a news literacy project now more than at any other time.

\section{Bibliography}

Agrawal A. (2015), Why we keep calling you Presstitutes: A message from the rest of us, 18.12.2015, Scroll.in, https://scroll.in/article/776386/why-we-keep-calling-you-presstitutes-a-messagefrom-the-rest-of-us, 28.06.2019.

Bulger M., Davison P. (2018), The Promises, Challenges, and Futures of Media Literacy, Data \& Society, https://datasociety.net/pubs/oh/DataAndSociety_Media_Literacy_2018.pdf, 30.06.2019.

Centre For News Literacy, What Is News Literacy?, Stony Brook University School Of Journalism, https://www.centerfornewsliteracy.org/, 30.06.2019.

Chakrabarti S. (2018), Nationalism a driving force behind fake news in India, research shows, 12.11.2018, BBC News, https://www.bbc.com/news/world-46146877, 25.06.2019.

Chakrabarti S., Duty, Identity, Credibility, Fake news and the ordinary citizen in India, BBC News, http://downloads.bbc.co.uk/mediacentre/duty-identity-credibility.pdf, 27.06.2019.

Correspondent (2017), Rewriting history: Akbar lost to Maharana Pratap; Mahatma, Nehru missing from texts, 25.07.2017, "Hindustan Times", https://www.hindustantimes.com/india-news/ rewriting-history-akbar-lost-to-maharana-pratap-no-mahatma-or-nehru-in-texts/story-N0xOT7Pqq6XGEvAgFXnBvI.html, 30.06.2019.

Ericsson, Future mobile data usage and traffic growth, ericsson.com, https://www.ericsson.com/en/ mobility-report/future-mobile-data-usage-and-traffic-growth, 24.06.2019.

FM Staff (2019), Rise Of Hatred And Violence Linked To Fake News, 22.01.2019, "Focus magazine", https://www.focusmagazine.in/rise-of-hatred-and-violence-linked-to-fake-news/, 28.06.2019.

Ghosh D. (2019), Elections 2019: Press Conference That Wasn't? PM Narendra Modi Lets Amit Shah Do The Talking, 18.05.2019, NDTV, https:/www.ndtv.com/india-news/elections-2019-pmnarendra-modi-addresses-first-press-conference-2039109, 29.06.2019.

Iqbal M. (2019), WhatsApp Revenue and Usage Statistics, 19.02.2019, BusinessofApps, https://www. businessofapps.com/data/whatsapp-statistics/, 26.06.2019.

Kaushik K. (2016), The Big Five: The Media Companies That the Modi Government Must Scrutinise To Fulfill its Promise of Ending Crony Capitalism, 19.01.2016, "The Caravan", https://caravanmagazine.in/vantage/the-big-five-the-media-companies-that-the-modi-government-mustscrutinise-to-fulfill-its-promise-of-ending-crony-capitalism, 28.06.2019.

Media Ownership Monitor (2019), Who owns the media in India?, 31.05.2019, Reporters Without Borders, https://rsf.org/en/news/media-ownership-monitor-who-owns-media-india, 27.06.2019.

Meeker M. (2018), Internet Trends Report 2018, 30.05.2018, Kleiner Perkins, https://www.kleinerperkins.com/perspectives/internet-trends-report-2018/, 26.06.2019.

Mitter S. (2019), India leads the world in time spent on video-streaming apps, Netflix most downloaded paid app, 18.01.2019, YourStory, https://yourstory.com/2019/01/india-netflix-top-paid-app, 25.06.2019. 
Mobility Report, June 2019, https://www.ericsson.com/en/press-releases/2019/6/ericsson-mobilityreport-5g-uptake-even-faster-than-expected, 12.07.2019.

Office of the Registrar General and Census Commissioner, India 2001, Census Data Census And You/ Literacy And Level of Education, http://censusindia.gov.in/Census_And_You/literacy_and_level_of_education.aspx, 27.06.2019.

Owen L. H. Can we keep media literacy from becoming a partisan concept like fact checking?, 23.02.2018, NiemanLab, https://www.niemanlab.org/2018/02/can-we-keep-media-literacyfrom-becoming-a-partisan-concept-like-fact-checking/, 29.06.2019.

Press Trust of India (2018), India's mobile subscriber base to touch 1.42 billion by 2024, 80\% to use 4G, 27.11.2018, "The Economic Times", https://economictimes.indiatimes.com/telecom/indias-mobile-subscriber-base-to-touch-1-42-billion-by-2024-80-to-use-4g/articleshow/66830785. cms?from=mdr, 24.06.2019.

Press Trust of India (2019), Facebook expands fact-checking network in India, adds 5 more partners to spot fake news, 11.02.2019, "The Economic Times", https://economictimes.indiatimes.com/tech/internet/facebook-expanding-fact-checking-in-india-before-election/articleshow/67940960.cms?from=mdr, 29.06.2019.

Press Trust of India (2019), India drops down on World Press Freedom Index, 18.04.2019, "The Economic Times", https://economictimes.indiatimes.com/news/politics-and-nation/india-dropsdown-on-world-press-freedom-index/articleshow/68940683.cms, 29.06.2019.

Saldanha A., Rajput P., Hazare J. (2018), Child-Lifting Rumours: 33 Killed In 69 Mob Attacks Since Jan 2017. Before That Only 1 Attack In 2012, 9.07.2018, IndiaSpend, https://www.indiaspend.com/ child-lifting-rumours-33-killed-in-69-mob-attacks-since-jan-2017-before-that-only-1-attackin-2012-2012/, 25.06.2019.

Soni A. (2017), India: Using Legal Action to Silence Journalists, 10.08.2017, Global Investigative Journalism Network, https:/gijn.org/2017/08/10/paranjoy-guha-thakurta-using-legal-actionto-silence-journalists/, 29.06.2019.

Special Correspondent (2018), Indian journalism going through its worst phase, 16.07.2018, "The Hindu", https://www.thehindu.com/news/national/karnataka/indian-journalism-going-throughits-worst-phase/article24430376.ece, 30.06.2019.

Special Correspondent (2019), At 9.8 GB per month, India has the highest data usage per smartphone, 20.06.2019, "The Hindu”, https:/www.thehindu.com/business/Industry/india-has-highest-data-usage-report/article28078254.ece, 24.06.2019.

Sydow L. (2019), The State of Mobile in 2019 - The Most Important Trends to Know, 16.01.2019, App Annie-Blog, https:/www.appannie.com/en/insights/market-data/the-state-of-mobile-2019/, 27.06.2019.

The Economis Times, April 18, 2018, https://economictimes.indiatimes.com/news/politics-and-nation/ india-drops-down-on-world-press-freedom-index/articleshow/68940683.cms, 30.06.1919.

\section{Przegląd ekosystemu „fake news" w Indiach a potrzeba zastosowania projektu News Literacy}

\section{Streszczenie}

Tylko w ostatnim roku ponad 30 osób zginęło w Indiach z powodu pogłosek o porwaniach dzieci rozpowszechnianych w mediach społecznościowych, a w szczególności za pośrednictwem WhatsApp. Dostępność Internetu w Indiach istotnie wzrosła w ostatnich latach dzięki wejściu na rynek Reliance Jo, które uczyniło pakiety danych tańszymi, a przez to bardziej dostępnymi. WhatsApp był najczęściej pobieraną aplikacją. Podczas gdy kraj przygotowywał się do ważnych wyborów, rozpowszechnianie dez- 
informacji uległo przyspieszeniu. Rządząca partia prawicowa stwierdziła, że w jej grupach WhatsUp uczestniczą ponad 3 miliony osób. Niedawny raport BBC pokazał, iż największa ilość dezinformacji w kraju jest rozpowszechniana przez środowiska prawicowe. Bez względu na to, czy nazwie się to propagandą, dezinformacją czy oczywistymi „fake newsami”, fałszywa lub nieprawdziwa informacja stała się częścią procesu politycznego w Indiach. Co więcej, w ciągu ostatnich kilku lat, indyjskie media zdają się nie sprzeciwiać rządowi i zasadniczo wspierają linię władz. Powodów takiego stanu rzeczy jest kilka i należą do nich korporacyjna własność mediów, regresywne regulacje prawne, jak również całkowite pomijanie mediów przez rządzących. Premier rozmawiał jedynie z kilkoma wybranymi domami medialnymi i w ciągu 5-letniej kadencji nigdy nie otrzymał trudnych pytań. Co więcej, rząd całkowicie pominął media, zwracając się do społeczeństwa bezpośrednio za pomocą mediów społecznościowych. Wszystkie te czynniki tworzą bardzo nabrzmiałą i chaotyczną sytuację informacyjną. Z uwagi na ingerencję rządu w edukację dla większości edukatorów wprowadzanie kursów krytycznego myślenia stało się znacznie trudniejsze. Dzieje się tak mimo podejmowania przez Google News Initative, Facebook czy BBC Schools wysiłków na rzecz wprowadzenia narzędzi do weryfikowania fałszywych informacji.

Słowa kluczowe: News Literacy, fake news, WhatsApp, media społecznościowe, Factchecking 
